\title{
The repurchase by a holding company of treasury shares held by subsidiaries: A South African perspective
}

\author{
N Wesson* and WD Hamman \\ University of Stellenbosch Business School, \\ PO Box 610, Bellville 7535, Republic of South Africa \\ nwesson@telkomsa.net
}

Received June 2012

\begin{abstract}
This study aims to establish whether the repurchasing of treasury shares by a holding company is a regular occurrence for companies listed on the Johannesburg Stock Exchange (JSE); whether these repurchasing companies have complied with the relevant legal and reporting requirements; and what their stated motivations were for these repurchases.

In a sample of 251 companies listed on the JSE from 1999 till their 2009 financial year-end, 120 (47,8\%) companies executed share repurchases. Thirty-six (30\%) of the 120 companies repurchased treasury shares from their subsidiaries in 55 different transactions, representing $22 \%$ of the total number of shares repurchased.

Companies which repurchase treasury shares do not always comply with the legal requirements (such as obligatory Security News Agency (SENS) announcements and circulars); and the accounting requirements of International Financial Reporting Standards (IFRS) (relevant to the disclosure of the reconciliation of the number of shares in issue) are applied in an inconsistent manner in annual reports. The most common reason for the repurchase of treasury shares was that the $10 \%$ limit (on treasury shares held by subsidiaries) had nearly been reached. Various business purposes were also given. Income tax implications did not seem to be a conclusive motivation for repurchasing treasury shares.

The repurchase of treasury shares by the holding company is not allowed in most other countries, like the UK, and presents unique challenges to the South African share repurchase environment. More stringent application of the JSE Listing Requirements, as well as better guidance on the IFRS disclosure requirement on the reconciliation of the number of shares in issue, is needed in South Africa. This will enable stakeholders to make better-informed decisions and will also assist research on share repurchases.
\end{abstract}

This material is based upon work supported financially by the National Research Foundation. However, any opinions, findings, conclusions and recommendations expressed in this article are those of the authors alone, and the NRF does not accept any liability in regard thereto.

*To whom all correspondence should be addressed.

\section{Introduction}

Share repurchases were introduced in South Africa on 1 July 1999 in terms of Section 85 to 90 of the Companies Amendment Act, Act 37 of 1999 (RSA, 1999). Companies may acquire their own shares, and subsidiaries may acquire up to $10 \%$ of the shares in their holding company in terms of the Act. The shares acquired by the subsidiaries are referred to as treasury shares for accounting purposes. These treasury shares may later be sold either to external parties or to parties within the group. The repurchase of the treasury shares by the holding company make way for subsidiaries again to repurchase shares in the holding company (until the $10 \%$ threshold is reached).

Most countries do not allow subsidiaries to acquire shares in their holding company. The repurchase of treasury shares by the holding company therefore does not occur in most countries. In countries where these repurchases are allowed, the accounting, legal and income tax principles may differ from the South African principles.

The repurchase of treasury shares by the holding company has been identified as a South African share repurchase method in an exploratory study on share repurchases (Bester, Wesson \& Hamman, 2010). The present study aims to establish how many treasury shares were repurchased by companies listed on the Johannesburg Stock Exchange (JSE) during the period 1 July 1999 till December 2009. The motivations, income tax implications, and legal and reporting requirements on these repurchases will also be addressed.

\section{Literature review}

South African legislation allows three types of group entities to repurchase shares in the holding company, i.e. the holding company, its subsidiaries and its share trusts. Share trust 
repurchases are not researched in this study. This study deals with shares that were held by subsidiaries (i.e. treasury shares) and then sold to the holding company. A brief overview of the South African repurchase environment, as well as an international comparison, is however needed to understand this specific aspect of share repurchases, namely of treasury shares sold back to the holding company.

\section{Legal and reporting framework for share repurchases}

Share repurchases by the holding company and its subsidiaries require a special resolution [Section 85 (1) of the Act] (RSA, 1999). The share repurchases may be executed under general authority (i.e. a general repurchase) or under specific authority (i.e. a specific repurchase). General authority refers to shares acquired in the open market and specific authority refers to a pro rata offer or a specific offer [Section 5.69 of the Listing Requirements] (JSE, 2007). The general authority is valid till the next general meeting or for 15 months from the date of the resolution, whichever period is the shorter [Section 5.67(h)] (JSE, 2007), while the specific authority is binding and needs to be executed by the company, except if permitted not to do so by the JSE [Section 5.69(g)] (JSE, 2007). All shares repurchased by the holding company are cancelled from issued share capital [Section 85(8)] (RSA, 1999), whereas the shares repurchased by the subsidiaries are not cancelled from issued share capital [Section 89] (RSA, 1999).

The announcement of share repurchases to the JSE depends on whether the repurchase was executed under general or specific authority. Shares repurchased under general authority are announced through the Security News Agency (SENS) of the JSE only once a company has cumulatively acquired 3\% of its initial number of issued shares (of that class, as at the date of the resolution) and each 3\% thereafter [Section 11.27] (JSE, 2007). A specific share repurchase must be announced via SENS once the terms have been agreed upon. Within 28 days of publication of the announcement on a specific repurchase, a circular needs to be sent to both the JSE and then to all shareholders [Section 11.23 and 11.25] (JSE, 2007).

The disclosure requirements on share repurchases in the company annual report are included in two International Financial Reporting Standards (IFRS), i.e. IAS 1 Presentation of financial statements (SAICA, 2009a) and IAS 32 Financial instruments: Presentation (SAICA, 2009b). Paragraph 79 (a) (iv) and (vi) of IAS $I$ require an entity to disclose (either in the statement of financial position or the statement of changes in equity, or in the notes), for each class of share capital, a reconciliation of the number of shares outstanding at the beginning and at the end of the period, as well as shares in the entity held by the entity or by its subsidiaries or associates. Paragraph 33 of IAS 32 requires that shares repurchased by entities in the group (e.g. treasury shares) be deducted from equity in the group annual report. The deduction of treasury shares from the company shares in the group annual report is in line with the consolidation principle followed in the group annual report.
As the present study deals with a specific aspect of share repurchases, i.e. the repurchase by the holding company of treasury shares held by subsidiaries, it is necessary to apply the requirements above to this repurchase method. The initial repurchase of the treasury shares by the subsidiary is a share repurchase under Section 89 of the Act and may be executed under general or specific authority. The subsequent repurchase of the treasury shares by the holding company is a repurchase in terms of Section 85 of the Act and must be executed under specific authority (as the identity of the selling party will be stipulated in the special resolution authorising the repurchase).

The following legal and reporting requirements therefore apply to the repurchase of treasury shares by the holding company:

- A SENS announcement needs to be made once the terms of the share repurchase have been agreed upon (as required by Section 11.25 of the Listing Requirements).

- A circular needs to be sent to the JSE and distributed to all shareholders (as required by Section 11.23 and 11.25 of the Listing Requirements).

- The disclosure requirements on the reconciliation of the number of shares outstanding at the beginning and at the end of the period need to be complied with (as required by $I A S 1$, paragraph 79 (a) (iv)).

\section{Income tax requirements}

Share repurchases executed under Section 85 of the Companies Act are treated as dividends for income tax purposes for the period researched in this study (i.e. 1 July 1999 till December 2009). Therefore, shares repurchased by the holding company are treated as a dividend. Secondary tax on companies (STC) is payable on the dividend paid by a company and is governed by Sections 64B and 64C together with the definition of "dividend" in section 1 of the Income Tax Act 58 of 1962 (RSA, 1962). The STC rate was $12,5 \%$ in respect of the periods 1999 till September 2007 and 10\% from October 2007 till December 2009. In terms of section 64J of the Income Tax Act of 1962 (RSA, 1962), dividends paid are not subject to STC to the extent that the dividend does not exceed the STC credit of the company. A STC credit results from dividends received by the company. The availability of STC credits is however unique to each company and will not be incorporated for the purposes of this study.

On the other hand, repurchases of shares by a subsidiary in a holding company (i.e. treasury shares) are not regarded as a dividend and are therefore not subject to STC.

The income tax requirements applicable to the specific aspect of share repurchases researched in this study, i.e. the repurchase by the holding company of treasury shares held by subsidiaries, are stated in Section $64 \mathrm{~B}(5)(\mathrm{f})$ of the Income Tax Act (RSA, 1962) and have undergone three major changes since the inception of share repurchases in South Africa (i.e. 1 July 1999). For periods ending 11 
December 2002, companies could choose whether the repurchase of the treasury shares should attract STC. For periods 12 December 2002 till 30 September 2007, the repurchase of treasury shares did not attract STC for the holding company. For periods beginning on or after 1 October 2007 till December 2009, the repurchase of the treasury shares is a share repurchase executed under Section 85 of the Companies Act and is subject to STC.

For income tax purposes, the repurchase by the holding company of treasury shares held by subsidiaries therefore had a STC-free period (prior to 1 October 2007, assuming that a company elected not to pay STC) and a STC-payable period (as from 1 October 2007).

\section{International comparison}

Most countries (e.g. United Kingdom (UK), Canada and Australia) only allow share repurchases by the holding company and disallow share repurchases of holding companies' shares by subsidiaries (Bhana, 2006: 241, 249). Countries either require shares repurchased by the holding company to be cancelled from issued and authorised share capital (e.g. Australia), shares repurchased to be cancelled only from issued share capital (e.g. Canada) or shares repurchased to remain as issued shares of the company, subject to the resale or cancellation thereof by the company (e.g. UK and USA) (Cassim, 2003: 144-145, 151).

Most international exchanges require companies to announce their share repurchases immediately after repurchases have been implemented - either on the day preceding the announcement (e.g. UK, Hong Kong, Canada and Australia), a week after the repurchase (e.g. France) or at the end of the quarter (e.g. USA) (Kobokoane, 2007: 1617; Mitchell \& Dharmawan, 2007: 149; Ginglinger \& Hamon, 2007: 919).

The tax treatment of share repurchases and dividends differ from country to country. In most countries dividends paid by a company are not liable for STC, but a withholding tax (i.e. shareholder tax) is applicable.

For the purposes of this study, it is necessary to highlight the differences between South Africa and the UK. South Africa and the UK apply IFRS for accounting purposes. IFRS are issued by the International Accounting Standards Board (IASB), situated in the UK. UK legislation on share repurchases however differs from South African legislation. UK share repurchases by the holding company are not cancelled, but are treated as treasury shares. These treasury shares may then be sold or transferred by the company. There is no obligation to cancel the shares, except if they cease to be qualifying (i.e. listed) shares (as defined in Section 162 of the UK Companies Act of 1985) (UK, 1985). In the UK subsidiaries may not acquire shares in the holding company. The repurchase by the holding company of treasury shares held by subsidiaries therefore does not occur in the UK. Shares repurchased by the company are announced to the UK securities exchange on a daily basis. STC is not payable on dividends in the UK. A withholding tax system applies and shareholders are taxed (income tax or capital gains tax) on the proceeds of shares sold under a share repurchase scheme.

It is therefore evident that the South African repurchasing environment differs from that of the UK. It may therefore be difficult for South African companies to interpret the accounting requirements of IFRS correctly. The different income tax treatment of share repurchases in South Africa may influence South African companies (and their subsidiaries) when repurchasing (and selling) treasury shares. The fact that South African specific repurchases always need to be announced via SENS may enable the compilation of a comprehensive dataset on specific repurchases and will simplify research on specific share repurchases. This study attempts to verify whether South African companies comply with these Listing Requirements.

\section{Related South African research on share repurchases}

Since the introduction of South African share repurchases on 1 July 1999, limited empirical research has been conducted. The legal implications of share repurchases were, however, researched and published in many academic journals. Of specific relevance is a study by Butler (1999) on the interpretation of Section 89 of the Act (RSA, 1999) which allows subsidiaries to acquire a maximum of $10 \%$ of the shares of their holding company. According to Butler (1999: 299), it is not clear how the $10 \%$ should be calculated and it is uncertain whether shares cancelled according to Section 85 (relating to the repurchase of the company's own shares) should be taken into account. In response to Butler's comments, the authors can add that it may be assumed that Section 85 repurchases need to be deducted as these repurchases are cancelled from issued shares in terms of Section $85(8)$. It is also evident that the $10 \%$ rule can only be applied when authorisation is sought for the repurchase of the shares by the subsidiary (in terms of Section 89). Any subsequent repurchase of a company's own shares (in terms of Section 85) will increase the percentage held by the subsidiary and will affect the future authorisation on subsidiary repurchases. There is therefore a difference between shares held by subsidiaries (which may exceed $10 \%$ ) and the authorisation granted to subsidiaries to acquire shares in the holding company (which may only be granted up to a maximum of $10 \%$ ).

Empirical research on South African share repurchase activities has thus far been based predominantly on share repurchases that were announced via SENS.

Both Daly (2002) and Bhana (2007) researched the information-signalling hypothesis. Daly's research sample comprised the 3\% SENS announcements of actual general share repurchases, whereas Bhana's research sample consisted of general repurchase announcements of intention to repurchase, irrespective of whether the repurchases were actually executed. Daly analysed the share returns of 45 JSE-listed companies that made 88 repurchase announcements between 1 July 1999 and 30 September 2001 (Daly, 2002). Bhana's research covered the period October 2000 to March 2003 and his sample comprised 117 repurchase announcements (Bhana, 2007). 
In a study by Bester (2008), it was found that 121 JSE-listed companies made 312 repurchase announcements via SENS over the period from July 1999 to June 2007. These announcements included general and specific repurchases, but did not consistently include announcements about repurchases by the company from its subsidiaries and excluded share trusts. The focus of Bester's study was to update shareholder distribution trends for JSE-listed industrial companies to determine the impact of share repurchases on dividend payouts.

In a recent study by Chivaka, Siddle, Bayne, Cairney and Shev (2009), the reasons that motivate South African executives to repurchase shares were investigated. The study was conducted by scrutinising circulars on specific repurchases for the stated reasons. A total of 55 repurchases (by 47 companies) in the time period 1999 to the end of 2004 were examined. Specific details of the repurchase announcements (i.e. dates and names of the companies) were not listed in the study. The most frequently stated reasons were: to eliminate odd lots $(14 \%)$, to increase earnings per share $(13 \%)$ and to increase net asset value per share $(10 \%)$. The study, however, concluded that, for all potentially contentious issues (where the reasons for share repurchases potentially affect the interests of multiple stakeholders), there is a significant difference between the theoretical reasons and the stated reasons of executives. Two prominent theoretical reasons, namely the signalling mechanism and tax efficiency, were conspicuously absent from the reasons stated in the circulars. Although the underlying reasons are not overtly stated, they may well be in line with theory (Chivaka et al., 2009).

The objective of a study by Firer, Gilbert and Maytham (2008) was to obtain the key factors that drive dividend and share repurchase policies of South African firms and also to compare these views to modern dividend theories. A questionnaire was sent to 312 directors of JSE-listed companies on 16 August 2006. Only 46 (15\%) responses could however be used in the analysis.

A study by Bester, Hamman, Brummer, Wesson and SteynBruwer (2008) found that share repurchases introduced additional complexity to financial reporting. Dataset requirements were met by scrutinising the disclosures on share capital and market capitalisation of JSE-listed companies that participated in share repurchases and that disclosed their market capitalisation in their 2006 annual report. It was found that only about $25 \%$ of the 63 JSE-listed companies (included in the former industrial sector of the JSE) which published market capitalisation based it on the correct number of group shares (i.e. after the deduction of treasury shares). About $75 \%$ of the JSE-listed companies which published market capitalisation did not base their calculation on the number of group shares: they omitted to deduct subsidiary repurchases and/or trust consolidations in their calculation of the number of shares. It was also found that the JSE, when calculating market capitalisation (as obtained from McGregor BFA: product called Price Data), based the calculation on the number of company shares (i.e. before the deduction of treasury shares). This leads to the overstatement of market capitalisation of companies involved in share repurchases via subsidiaries and share trusts.

Bester et al. (2010) conducted an exploratory study by combining data obtained from share repurchases announced via SENS and from disclosures in annual reports in order to obtain a comprehensive dataset on share repurchases. A sample of 33 JSE-listed companies, for the period 1999 till the 2008 financial year-end of the specific company, was selected. The 33 companies repurchased a total of 2306193555 (with a value of R52 133169 286) shares during the research period. The following trends in share repurchase activities were identified: $59 \%$ of general share repurchases in volume (and 49,3\% in value) are not reported via the 3\% SENS announcements; actual general share repurchases represent $47,9 \%$ in volume (and 60,5\% in value) of total share repurchases; and share repurchases in volume are affected as follows by the different reporting entities: $26,1 \%$ own shares repurchased by the company, $56,8 \%$ repurchased by subsidiaries, $17,1 \%$ subsequently repurchased by the company from subsidiaries. The conclusion was made that South African studies on share repurchases that are solely based on announced general share repurchases do not reflect a comprehensive study of share repurchases. It was also highlighted that aspects unique to the South African repurchase environment (i.e. repurchases by subsidiaries and share trusts, and the subsequent repurchase of treasury shares by the holding company) need to be addressed in South African research on share repurchases.

Wesson and Hamman (2011) selected 15 JSE-listed companies and compared the annual report disclosure (in the most recent annual report) on the movement in number of shares in issue to the requirements stated in IAS 1 paragraph 79. It was found that three companies (20\%) did not disclose a reconciliation of the number of shares; eight companies $(53,3 \%)$ did not disclose a reconciliation of the number of group shares; and eight companies $(53,3 \%)$ did not disclose a reconciliation of the number of treasury shares held. It was concluded that the disclosure requirements are interpreted inconsistently by reporting entities and that a South African interpretation of Statements of Generally Accepted Accounting Standards is needed to clarify the distinction between "company shares", "group shares" and "treasury shares". The fact that the IFRS are issued in the UK, where legislation differs from the share repurchase legislation in South Africa, was identified as a possible reason for the inconsistent application.

\section{Motivations for the repurchase of treasury shares}

The present study deals with the repurchase of treasury shares (held by subsidiaries) by the holding company. This repurchase method is executed under a specific authority (i.e. specific repurchase). The study of Chivaka et al. (2009) researched motivations stated by executives in the circulars of the announced specific repurchases. The conclusion of the Chivaka et al. study (2009) was however that for all potentially contentious issues (e.g. the signalling mechanism and tax efficiency) there is a significant difference between the theoretical reasons and the stated reasons of executives. 
The authors of the current study therefore identify the need for a logical explanation of possible motivations for the repurchase by the holding company of treasury shares held by subsidiaries. These transactions may be motivated by a number of factors. Each company has unique circumstances and needs, and their motivations may differ.

Examples of reasons why a subsidiary may seek to acquire shares in the holding company include:

- To transfer the repurchased shares to a share incentive trust or to the beneficiaries of a share option scheme or employee incentive scheme.

- To utilise the repurchased shares as payment in a business transaction.

- To structure a Black Economic Empowerment (BEE) transaction.

- To utilise the investment opportunity when the share price is trading below net asset value.

- To utilise the advantage of no STC payable on share repurchases by subsidiaries.

Examples of reasons why a holding company may seek to repurchase the treasury shares held by the subsidiary include:

- The business purposes identified as motivations to hold the treasury shares in the subsidiary (as stated above) are no longer applicable.

- The $10 \%$ limit (on treasury shares held by subsidiaries) has been reached.

- To utilise the advantage of no STC payable on these share repurchases (only applicable to periods prior to 1 October 2007).

The examples above do not refer to the general theories associated with share repurchases, e.g. signalling hypothesis, under-reaction hypothesis, agency theory, etc. They are listed only as examples of why a company may seek rather to utilise a subsidiary for the repurchase (and not the holding company itself). The fact that treasury shares acquired by a subsidiary are not cancelled from issued capital (and can therefore be utilised for a specific purpose), while timing the purchase price at a price below net asset value are the main features underlying the above-mentioned examples of motivations.

The present study however only focuses on motivations for the repurchase of the treasury shares by the holding company.

\section{Research problem and objectives}

Limited research has been conducted in South Africa on share repurchases over the past 12 years. The main reason for the limited research is the lack of a comprehensive database.
The South African share repurchase requirements differ from what is required in other countries. The repurchase of treasury shares (held by subsidiaries) by the holding company is an example thereof.

The following research questions are addressed in this study:

1. Is the repurchase of treasury shares by a holding company a regular occurrence for JSE-listed companies?

2. Do JSE-listed companies comply with the legal and reporting requirements for this repurchasing method?

3. What are the motivations, as stated in publicly available information, for the repurchase of treasury shares by JSE-listed companies?

The aim of answering these research questions is to document and increase the understanding of the South African repurchase environment. This study also seeks to contribute to establishing a comprehensive database on share repurchases by JSE-listed companies.

\section{Collection of data}

This study required data on the number of subsidiary treasury shares repurchased by holding companies (specifying the repurchasing entity and repurchase method) over the stipulated research period; evidence on whether the legal and reporting requirements were met; and the motivations for the repurchase.

As none of the financial data-providing agencies in South Africa, like Reuters, McGregor BFA or I-Net Bridge, keep detailed records on share repurchase activities, the data on the number of shares were obtained by using the same methods of data collection as were used in the Bester et al. (2010) exploratory study.

Three data collection methods were combined to obtain a comprehensive dataset of number of shares repurchased. The first method was to record SENS announcements (as obtained from McGregor BFA (product called News)) of companies' intentions to conduct repurchases. Information regarding specific repurchases searched in this manner is quite reliable because these offers usually result in actual repurchases after being accepted by shareholders. However, announcements of intentions to repurchase via general authority hold little resemblance to actual repurchases, owing to the fact that a general offer does not constitute a binding commitment.

The second, additional method used was to collect all the SENS announcements (as obtained from McGregor BFA (product called News)) in respect of actual share buy-backs under general (the incremental 3\% announcements) and specific authority. The general repurchases announced under the cumulative $3 \%$ rule however do not include all general repurchases, as general repurchases totalling less than the cumulative $3 \%$ need not be announced. 
The third and significantly more labour-intensive method adopted was to determine the actual shares repurchased by analysing the annual reports of all JSE-listed companies from 1999 to 2009 and noting changes in the number of shares issued. Each director's report, share capital note to the balance sheet (or statement of financial performance), statement of changes in equity and shareholder analysis (or shareholder spread) of annual reports were carefully scanned for changes in issued shares, including treasury shares held by subsidiaries. Although this method proved to be immensely time-consuming, a distinction could be made between repurchases by the company (that were cancelled) and repurchases and sales by subsidiaries (not cancelled but regarded as treasury shares and consolidated). All the data requirements for method three were obtained from the published annual reports of the companies (hard copies) and, failing this, were downloaded either from the annual reports on the Internet or from McGregor BFA (product called Library).

All three methods of data collection on share repurchase activity were then compared to confirm that no repurchase activities had been omitted, and to identify all repurchase methods and repurchasing entities. The number of shares and number of transactions in which treasury shares (held by subsidiaries) were repurchased by the holding company were of specific interest for the purposes of this study.

The data needed to establish whether holding companies had complied with legal and reporting requirements entailed obtaining evidence of repurchases announcements via SENS as well as in circulars. All treasury share repurchases by the holding company (in number of shares and number of transactions) that were identified in the three methods of data collection were therefore compared to SENS announcements and circulars (as obtained from McGregor BFA (product called News)). Evidence of whether companies disclosed the movement in the number of shares in issue (company, group and treasury shares) in their annual reports was obtained by scrutinising the directors' reports, share capital notes and treasury share notes in the annual reports.

The data requirements for the motivations on the repurchase by the holding company of treasury shares held by subsidiaries were met by scrutinising the relevant SENS announcements and circulars as well as the annual reports for reasons stated by the holding company. Data on income tax as a possible motivation for the cancellation of the treasury shares held by the subsidiaries were obtained by noting the dates of the cancellation of the shares repurchased from issued capital (as obtained from McGregor BFA (product called Price Data)) and by comparing them to the dates stipulated in the Income Tax Act relating to STC-free and STC-payable periods.

\section{Problems encountered when collecting data}

The following problems were encountered when collecting data on treasury shares repurchased by the holding company:
- It was found that annual report disclosures on the movement in the number of shares were inconsistent. A detailed reconciliation of the number of group shares and the number of treasury shares was not always disclosed. Treasury shares repurchased by the holding company were therefore not always evident from annual report disclosures. For SENS announcements on treasury share repurchases that were not specifically disclosed in the annual report, the statement of changes in equity of the group and company were compared to confirm the treasury share repurchase. The cancellation of the shares was confirmed by verifying the daily movement in number of company shares (as obtained from McGregor BFA (product called Price Data)).

- Treasury shares repurchased by the holding company may be executed in more than one transaction. For the purpose of this study the number of transactions in which the treasury share repurchases occurred were calculated on the basis of the annual report disclosure (which usually combines the repurchases in one transaction description per annum) and SENS announcement disclosure (which state each transaction separately). Treasury share repurchase transactions that were not announced via SENS could therefore only be verified from annual reports. The number of transactions identified in this study could therefore be understated when derived from annual report disclosures.

- Annual report disclosures could only be verified till the final annual report that had been published. For delisted companies, a share repurchase prior to delisting but subsequent to the last published annual report, could only be confirmed in the SENS announcement and by verifying the daily movement in number of company shares (as obtained from McGregor BFA (product called Price Data)).

\section{Sample selection}

The following JSE-listed companies were included in the sample for the financial annual periods from 1 July 1999 until the 2009 year-end of the company:

- Companies with listed ordinary and/or N-shares;

- Companies with the JSE as their primary listing; and

- Companies not included in the Basic Materials, Financial and Banking, Alternative Exchange and Development Capital sectors of the JSE.

Odd lot offers were not treated as share repurchases as they had existed prior to 1999. Companies that fell within the sample requirements but were listed for fewer than three years were also excluded.

From 1999 to 2009, there were 251 companies (as defined in the sample selection) listed on the JSE, of which 107 were delisted during the period. Delisted companies were included (up to the date of their delisting) to ensure a comprehensive study of repurchase activities. 


\section{Research methodology}

In order to establish how many treasury shares (held by subsidiaries) were repurchased by holding companies in comparison with other share repurchases, the following methodology was followed:

1. The total share repurchases (the number of shares) were divided into three repurchasing categories, i.e. holding company repurchases (excluding repurchase of treasury shares from subsidiaries); subsidiary repurchases and holding company repurchases of treasury shares held by subsidiaries.

2. The percentage that the repurchases of treasury shares (held by subsidiaries) by the holding company represents of the total share repurchases was calculated.

In order to establish whether the announcement procedures, as required in terms of the Listing Requirements and IFRS, were adhered to by the repurchasing company:

1. It was verified whether an announcement on SENS and an announcement via a circular to shareholders were made, based on the identification of the repurchase of the treasury shares by the holding company in the SENS announcements and/or annual report disclosures.

2. It was established how the reconciliation of the movement in number of shares (as required by IFRS) was disclosed in the annual report of the companies that repurchased treasury shares from subsidiaries. Treasury shares repurchased by the holding company affects the movement in number of company shares (the number is reduced) as well as treasury shares (the number is also reduced), and therefore does not affect the number of group shares (because number of company shares less number of treasury shares equals number of group shares). Special note was taken whether the company disclosed a reconciliation for the number of company shares, number of group shares, as well as number of treasury shares.

In order to establish what the stated motivations were for the repurchase of treasury shares (held by subsidiaries) by the holding companies:

1. The motivations stated by companies in their SENS announcements, circulars and annual report disclosures were tabulated.

2. A note was made of the date of the share cancellation, and it was established whether the repurchase was made in a STC-free (prior to 1 October 2007) or STC-payable period (1 October 2007 till 31 December 2009).

\section{Results}

Occurrence of treasury shares repurchased by the holding company

It was found that 120 of the 251 companies $(47,8 \%)$ included in the sample engaged in share repurchase activities (by the holding company and/or subsidiaries) from 1 July 1999 until the 2009 financial year-end of the specific companies. A total number of 5810468266 shares were repurchased by the 120 companies.

The specific repurchase type researched in this study, i.e. the repurchase by the holding company of treasury shares held by subsidiaries, was executed by 36 of the 120 repurchasing companies $(30 \%)$. The 36 companies that repurchased treasury shares from their subsidiaries are listed in Table 1. A total number of 1283667153 treasury shares were repurchased by the 36 companies. The repurchases by holding companies of treasury shares held by subsidiaries therefore represent $22 \%$ of total share repurchases. These repurchases were executed in 55 different transactions. The first repurchase of treasury shares was made by Brandcorp Holdings on 11 September 2001.

The treasury share repurchases in six of the 55 transactions were initially obtained only from the SENS announcement and were not specifically disclosed in the annual reports. Two of these transactions (Comparex and Tiger Wheels) appeared in SENS announcements on share repurchases prior to the delisting of the company, but subsequent to the last published annual report. The six transactions were verified by following the procedures described in the data collection section under the problems encountered.

The number of treasury shares repurchased by the holding company reflects treasury shares that were held by subsidiaries prior to the sale thereof to the holding company. One of these transactions involves Netcare treasury shares that were repurchased from a Netcare subsidiary, Netpartner. Of these shares, 340354743 were initially acquired by Netpartner before becoming a subsidiary of Netcare. Although these shares were not initially repurchased by a subsidiary, they were sold by a subsidiary to the holding company. All aspects researched in this study apply to this transaction (e.g. it is a specific repurchase in terms of the Listing Requirements, it affects the disclosure on the reconciliation of the number of shares and it is a dividend in terms of the Income Tax Act) and it is therefore included in the dataset.

The number of treasury shares repurchased (i.e. 22\%) correlates positively with the results of the exploratory study of Bester et al. (2010). That study found that the 33 companies included in its sample repurchased a total of 2306193555 shares from 1 July 1999 until their 2008 financial year-end. The repurchase of treasury shares held by subsidiaries represented $393999684(17,1 \%)$ of total share repurchases. These treasury share repurchases were executed in 16 transactions. The number of companies entering into these transactions was however not stated in the study. 
Table 1: Companies repurchasing treasury shares from subsidiaries

\begin{tabular}{|c|c|c|c|}
\hline No. & Company name & No. of transactions & No. of shares \\
\hline 1 & Adcorp Holdings & 1 & 2255979 \\
\hline 2 & Allied Technologies & 1 & 1073729 \\
\hline 3 & Aspen Pharmacare Holdings & 2 & 57743148 \\
\hline 4 & Astral Foods & 2 & 388414 \\
\hline 5 & AVI & 1 & 27369006 \\
\hline 6 & Barloworld & 1 & 19090900 \\
\hline 7 & Brandcorp Holdings & 1 & 19015876 \\
\hline 8 & Chester Investment Holding & 1 & 17400000 \\
\hline 9 & Clicks Group & 5 & 80249784 \\
\hline 10 & Comparex Holdings & 1 & 31908116 \\
\hline 11 & Compu-Clearing Outsourcing & 2 & 5020627 \\
\hline 12 & Connection Group Holdings & 1 & 4724677 \\
\hline 13 & Control Instruments Group & 2 & 10148672 \\
\hline 14 & Digicore Holdings & 1 & 16034528 \\
\hline 15 & Distribution and Warehousing Network & 1 & 13419135 \\
\hline 16 & Dorbyl & 1 & 996790 \\
\hline 17 & Grindrod & 5 & 41356382 \\
\hline 18 & Iliad Africa & 1 & 7851111 \\
\hline 19 & Imperial Holdings & 1 & 14532422 \\
\hline 20 & Invicta Holdings & 1 & 6409281 \\
\hline 21 & Metrofile Holdings & 1 & 6877024 \\
\hline 22 & Nampak & 1 & 9475425 \\
\hline 23 & Netcare & 2 & 456410964 \\
\hline 24 & Paracon Holdings & 1 & 16000000 \\
\hline 25 & Pick n Pay Stores & 1 & 12585315 \\
\hline 26 & Primeserv Group & 1 & 14083512 \\
\hline 27 & Remgro & 2 & 46245462 \\
\hline 28 & Reunert & 1 & 563631 \\
\hline 29 & Sasol & 2 & 91611477 \\
\hline 30 & The House of Busby & 1 & 1491418 \\
\hline 31 & Tiger Wheels & 1 & 2298496 \\
\hline 32 & Transpaco & 1 & 2962908 \\
\hline 33 & Truworths International & 1 & 36214812 \\
\hline 34 & UCS Group & 2 & 27407711 \\
\hline 35 & Value Group & 3 & 13163007 \\
\hline \multirow[t]{2}{*}{36} & Woolworths Holdings & 2 & 169287414 \\
\hline & & 55 & 1283667153 \\
\hline
\end{tabular}

\section{Legal and reporting requirements}

Table 2 shows whether the companies executing the repurchase of treasury shares held by subsidiaries complied with the Listing Requirements relating to required SENS announcements and circulars to shareholders. Only 11 (20\%) of the 55 transactions, representing 347281323 $(27 \%)$ of the number of treasury shares repurchased, were announced via SENS and a circular. Treasury share repurchases relating to $18(32,7 \%)$ of the 55 transactions, representing $685599054(53,4 \%)$ of the number of treasury shares repurchased, were only announced via SENS. Three $(5,5 \%)$ of the 55 transactions, representing 41898090 $(3,3 \%)$ of the number of treasury shares repurchased, were only announced via a circular to shareholders. A total of 23 $(41,8 \%)$ of the 55 transactions were not announced via SENS or circulars and comprise 208888686 (16,3\%) of the total treasury shares repurchased by the holding companies.

Holding companies therefore do not always comply with the Listing Requirements relating to the SENS and circular announcements on specific share repurchases when they repurchase treasury shares. It seems as if companies do not recognise this repurchase method as a specific repurchase and merely see it as an internal group transaction that does not need to comply with the Listing Requirements on specific repurchases. The results of this study confirm the findings of Bester et al. (2010), where it was found that 8 $(50 \%)$ of the 16 treasury share repurchase transactions were not announced via SENS. The study of Bester et al. (2010) did not include the announcement via circulars in their research.

Table 3 shows whether companies disclosed the movement in the number of shares (as required by IFRS) in their annual reports. IFRS is not specific on whether reconciliations of the number of company, group and treasury shares are required or on the detail to be disclosed. A total of 53 of the 55 transactions were included in annual reports. Two of the 55 transactions (i.e. Comparex and Tiger Wheels) occurred subsequent to the last published annual report, but prior to the delisting of the company. The annual report disclosure on the 53 transactions comprises a reconciliation of number of company shares for 31 transactions (58,5\%); a 
reconciliation of number of group shares for 20 transactions $(37,7 \%)$ and a reconciliation of number of treasury shares for 15 transactions $(28,3 \%)$. It was also found that the reconciliation of the movement in company shares of another five transactions $(9,4 \%)$ (as disclosed in the annual reports of Compu-Clearing Outsourcing, Illiad Africa, Invicta Holdings and Paracon Holdings) was done for the rand values, but not for the number of company shares in issue. Only a rand value reconciliation of the movement in group shares was also done for another two transactions $(3,8 \%)$ (as disclosed in the annual report of Compu-Clearing Outsourcing). It was also found that companies do not always disclose each type of movement in number of shares in their reconciliations and that a net movement is disclosed by certain companies (e.g. Pick n Pay Stores, Connection
Group Holdings and Transpaco). IFRS requires the movement in number of shares to be disclosed in either the statement of financial position, the statement of changes in equity or in the notes, and for each class of share capital. It was found that the disclosure on the movement in shares was done only in the directors' report in respect of two transactions $(3,8 \%)$ relating to number of company shares as well as number of group shares, and in respect of four transactions $(7,5 \%)$ relating to number of treasury shares. It was also found that the reconciliation of number of shares of two transactions $(3,8 \%)$ (as disclosed in the annual report of Sasol) combined the different types of shares in one reconciliation.

Table 2: Compliance with JSE Listing Requirements on specific repurchases

\begin{tabular}{l|c|c|c|c}
\hline & $\begin{array}{c}\text { No. of } \\
\text { transactions }\end{array}$ & \% & No. of shares & \% \\
\hline Announced in SENS and a circular & 11 & 20,0 & 347281323 & \\
\hline Announced only in SENS & 18 & 32,7 & 685599054 & 27,0 \\
\hline Announced only in a circular & 3 & 5,5 & 41898090 & 53,4 \\
\hline Unannounced & 23 & 41,8 & 208888686 & 3,3 \\
\hline Total & $\mathbf{5 5}$ & $\mathbf{1 0 0}$ & $\mathbf{1 2 8 3 6 6 7 ~ 1 5 3}$ & 16,3 \\
\hline
\end{tabular}

Table 3: Disclosure in annual report on reconciliation of movement of number of shares in issue

\begin{tabular}{|c|c|c|c|c|c|c|}
\hline & \multicolumn{2}{|c|}{$\begin{array}{c}\text { Reconciliation of } \\
\text { number of company } \\
\text { shares }\end{array}$} & \multicolumn{2}{|c|}{$\begin{array}{c}\text { Reconciliation of } \\
\text { number of group } \\
\text { shares }\end{array}$} & \multicolumn{2}{|c|}{$\begin{array}{c}\text { Reconciliation of } \\
\text { number of treasury } \\
\text { shares } \\
\end{array}$} \\
\hline & $\begin{array}{c}\text { No. of } \\
\text { transactions }\end{array}$ & $\%$ & $\begin{array}{c}\text { No. of } \\
\text { transactions }\end{array}$ & $\%$ & $\begin{array}{c}\text { No. of } \\
\text { transactions }\end{array}$ & $\%$ \\
\hline Reconciliation disclosed in annual report & 31 & 58,5 & 20 & 37,7 & 15 & 28,3 \\
\hline No reconciliation disclosed in annual report & 22 & 41,5 & 33 & 62,3 & 38 & 71,7 \\
\hline Total number of transactions included in annual reports & 53 & 100 & 53 & 100 & 53 & 100 \\
\hline
\end{tabular}

This study therefore finds that the requirements in IFRS on the reconciliation of the movement in number of shares are not applied consistently by reporting entities. It confirms the conclusion of Wesson and Hamman (2011), who found that, in a sample of 15 companies, only 12 companies (80\%) disclosed a reconciliation of number of company shares and seven companies $(46,7 \%)$ disclosed a reconciliation of number of group and treasury shares.

\section{Motivations}

Table 4 shows that $12(21,8 \%)$ of the 55 treasury share repurchase transactions were motivated by the fact that the $10 \%$ limit (on treasury shares held by subsidiaries) had nearly been reached. These transactions represent $721816781(56,2 \%)$ of the number of treasury shares repurchased. This indicates that these companies intend to continue to hold treasury shares in the subsidiary as the repurchase of the treasury shares by the holding company makes room for the subsidiary again to repurchase shares in the holding company. Ten $(18,2 \%)$ of the 55 transactions were motivated by various business reasons (e.g. to enable a BEE deal, unbundling of the company, liquidation of the company or capital restructuring). These transactions represent $230212743(17,9 \%)$ of the number of treasury shares repurchased. For $33(60 \%)$ of the 55 transactions no motivation was included in either the annual report, SENS announcement or circular. These transactions represent $331637629(25,9 \%)$ of the number of treasury shares repurchased.

Table 5 shows that $40(72,7 \%)$ and $15(27,3 \%)$ of the 55 transactions were respectively executed in the STC-free (i.e. from 1 July 1999 until 30 September 2007) and STCpayable (i.e. from 1 October 2007 until the 2009 year-end of the specific company) periods. In number of shares, these transactions represent $688675 \quad 104 \quad(53,6 \%)$ and $594992049(46,4 \%)$ treasury shares repurchased, respectively. The first treasury share repurchase occurred on 11 September 2001. The STC-free period therefore represents about six years of the period researched in this study, while the STC-payable period represents only about two years. The authors therefore extended the research period till the 2011 year-end of the companies that are included in the sample in order to include a more comparable STC-payable period (of four years). It was found that an additional seven treasury share repurchase transactions occurred subsequent to 2009, representing 117405471 shares. Therefore $40(64,5 \%)$ and $22(35,5 \%)$ of the 62 transactions were respectively executed in the STC-free (i.e. 1 July 1999 until 30 September 2007) and STC-payable (i.e. from 1 October 2007 until the 2011 year- 
end of the specific company) periods. In number of shares, these periods represent $688675104(49,2 \%)$ and 712397 $520(50,8 \%)$ treasury shares repurchased, respectively. Treasury share repurchases therefore still occur, irrespective of the negative income tax implications applicable since 1 October 2007.

The study thus found that various reasons were given by companies as to why they repurchase treasury shares, of which the reaching of the $10 \%$ limit was stated most often. Although $60 \%$ of the transactions (representing 25,9\% of the number of shares) did not include an explanation, it seems that the income tax treatment did not affect the occurrence of transactions.

The results of this study are not comparable with the Chivaka et al. study (2009), because the sample of specific repurchases in that study included shares repurchased from entities other than group entities, for which the most frequently stated reason was the elimination of odd lots, to increase earnings per share and to increase net asset value per share. An increase in earnings per share and net asset value per share is attributable to the fact that the share repurchases resulted in a decrease in the number of group shares in issue. The repurchase of treasury shares does not change the number of group shares. The number of group shares in issue will, however, decrease when the holding company repurchases shares from external parties (i.e. not entities in the group) and when subsidiaries repurchase shares in the holding company.

\section{Conclusion}

In an exploratory study by Bester et al. (2010), the repurchase of treasury shares by the holding company was identified as a South African share repurchase method. The study found that the repurchase of treasury shares by the holding company comprised $393999684(17,1 \%)$ of the total share repurchases of the 33 JSE-listed companies included in the sample, for the period 1 July 1999 until the 2008 financial year-end of the companies.
The purpose of the present study was to establish whether the repurchase of treasury shares by a holding company is a regular occurrence for JSE-listed companies; to discover whether legal and reporting requirements were met by these companies when repurchasing treasury shares; and to ascertain what the stated motivations for the repurchase of treasury shares were. All companies listed on the main board (excluding the Basic Materials, Financial and Banking sectors) of the JSE as from 1 July 1999 until their 2009 financial year-end were included in the sample. The sample comprised 251 companies.

This study found that $120(47,8 \%)$ of the 251 companies included in the sample entered into share repurchase activities (through the holding company and/or subsidiaries). Total share repurchases by the 120 companies amounted to 5810468266 shares. Treasury share repurchases by the holding company were conducted by 36 companies (i.e. $30 \%$ of the 120 companies) and represent $22 \%$ (i.e. 1283667153 shares) of total share repurchases. The 36 companies repurchased these treasury shares in 55 different transactions.

Only $11(20 \%)$ of the 55 transactions, which represent $27 \%$ (i.e. 347281323 shares) of the number of treasury shares repurchased, complied to the JSE Listing Requirements relevant to a SENS and circular announcement. A further 21 transactions $(38,2 \%)$ were announced either in SENS or in a circular. The remaining $23(41,8 \%)$ transactions, which represent 16,3\% (i.e. 208888686 shares) of the number of treasury shares repurchased, were not announced via SENS or in a circular.

The annual report disclosures, as required by IFRS, on the reconciliation of the movement of number of shares in issue were found to be done in an inconsistent manner. The disclosure on the 53 transactions included in the annual reports comprised a reconciliation of number of company shares for 31 transactions $(58,5 \%)$; a reconciliation of number of group shares for 20 transactions $(37,7 \%)$; and a reconciliation of number of treasury shares for 15 transactions $(28,3 \%)$.

Table 4: Motivations for the repurchase of treasury shares from subsidiaries

\begin{tabular}{l|c|c|c|c}
\hline & $\begin{array}{c}\text { No. of } \\
\text { transactions }\end{array}$ & \% & No. of shares & \% \\
\hline $10 \%$ limit reached & 12 & 21,8 & 721816781 & 56,2 \\
\hline Various business purposes & 10 & 18,2 & 230212743 & 17,9 \\
\hline No reasons stated & 33 & 60,0 & 331637629 & 25,9 \\
\hline Total & $\mathbf{5 5}$ & $\mathbf{1 0 0}$ & $\mathbf{1 2 8 3 6 6 7 1 5 3}$ & $\mathbf{1 0 0}$ \\
\hline
\end{tabular}

Table 5: Tax implications as a motivation for the repurchase of treasury shares from subsidiaries

\begin{tabular}{|c|c|c|c|c|}
\hline & $\begin{array}{c}\text { No. of } \\
\text { transactions }\end{array}$ & $\%$ & No. of shares & $\%$ \\
\hline Treasury shares repurchased 1/7/1999 until 30/9/2007 & 40 & 72,7 & 688675104 & 53,6 \\
\hline Treasury shares repurchased 1/10/2007 until 31/12/2009 & 15 & 27,3 & 594992049 & 46,4 \\
\hline Total & 55 & 100 & 1283667153 & 100 \\
\hline
\end{tabular}


The reason for the repurchase of treasury shares that was stated most frequently in the SENS announcements, circulars and annual reports was that the $10 \%$ limit (on treasury shares held by subsidiaries) had nearly been reached. This reason was stated in $12(21,8 \%)$ of the 55 transactions, representing $56,2 \%$ of the number of treasury shares repurchased. Ten $(18,2 \%)$ of the 55 transactions, representing $17,9 \%$ of the number of treasury shares repurchased, stated various business reasons (e.g. to enable a BEE deal, unbundling of the company, liquidation of the company or capital restructuring) as a motivation. No motivation was stated for $33(60 \%)$ of the 55 transactions, representing $25,9 \%$ of the number of treasury shares repurchased.

It was found that $40(72,7 \%)$ and $15(27,3 \%)$ of the 55 transactions were executed, respectively, in the STC-free (i.e. from 1 July 1999 until 30 September 2007) and STCpayable (i.e. 1 October 2007 until the 2009 year-end of the specific company) periods. In number of shares, these transactions represent $688675 \quad 104 \quad(53,6 \%)$ and $594992049(46,4 \%)$ treasury shares, respectively.

This study therefore concludes that the repurchase of treasury shares is a repurchase method used extensively by JSE-listed companies. There are various reasons why companies enter into treasury share repurchases by the holding company, of which income tax implications does not seem to be a conclusive motivation.

The repurchase of treasury shares by the holding company is unique to the South African repurchase environment. South African companies have not always complied with the Listing Requirements on specific share repurchases (relevant to required SENS announcements and circulars) and have applied disclosure requirements of IFRS (relevant to the reconciliations of the movement in number of shares) in an inconsistent way, mainly owing to the fact that an international precedent is not available. Incomplete announcements and disclosures on share repurchases not only affect research on share repurchases, but also impact negatively on the decisions to be made by shareholders, investors and analysts: without information on share repurchase activity, informed decisions cannot be made.

More stringent application of the Listing Requirements and better guidance on the detail to be included in the IFRS requirement on the reconciliation of the number of shares in issue are therefore needed in South Africa.

\section{References}

Bester, P.G. 2008. 'Shareholder distribution choices for industrial companies listed on the JSE: Share buybacks vs. dividends'. Unpublished MBA research report. Bellville: University of Stellenbosch.

Bester, P.G., Hamman, W.D., Brummer, L.M., Wesson, N. \& Steyn-Bruwer, B.W. 2008. 'Share repurchases: Which number of shares should be used by JSE-listed companies when publishing market capitalisation in annual reports', South African Journal of Business Management, 39(4): 4146.
Bester, P.G., Wesson, N. \& Hamman, W.D. 2010. 'Share buy-backs for a selection of JSE-listed companies: An exploratory study', South African Journal of Business Management, 41(4): 47-58.

Bhana, D. 2006. 'The company law implications of conferring a power on a subsidiary to acquire the shares of its holding company', Stellenbosch Law Review, 17(2): 232250 .

Bhana, N. 2007. 'The market reaction to open market share repurchases announcement: The South African experience', Investment Analysts Journal, 65: 25-36.

Butler, D. 1999. 'n Maatskappy se nuwe statutêre bevoegdheid om sy eie aandele te verkry: 'n Vertrekpunt', Stellenbosch Law Review, 10(3): 284-302.

Cassim, F.H.I. 2003. 'The repurchase by a company of its own shares: The concept of treasury shares', Stellenbosch Law Review, 120(1): 137-152.

Chivaka, R., Siddle, A., Bayne, L., Cairney, C. \& Shev, J. 2009. 'Reasons for share repurchases in South Africa: Theory versus practice', SA Journal of Accounting Research, 23(1): 1-30.

Daly, K.J. 2002. 'Share returns of companies announcing share repurchases under a general authority'. Unpublished MBA research report. Johannesburg: University of the Witwatersrand.

Firer, C., Gilbert, E. \& Maytham, A. 2008. 'Dividend policy in South Africa', Investment Analysts Journal, 68: 5-19.

Ginglinger, E. \& Hamon, J. 2007. 'Actual share repurchases, timing and liquidity', Journal of Banking \& Finance, 31(3): 915-938.

JSE. 2007. 'JSE Listing Requirements'. Service Issue no 3. Johannesburg. LexisNexis Butterworths. [online] URL:http://www.jse.co.za/listing_requirements.jsp.

Kobokoane, N. 2007. 'Share buybacks in South Africa: An empirical investigation'. Unpublished MBA research report. Bellville: University of Stellenbosch.

Mitchell, J.D. \& Dharmawan, G.V. 2007. 'Incentives for market buy-backs: Evidence from a transparent buy-back regime', Journal of Corporate Finance, 13(1): 146-169.

RSA (Republic of South Africa). 1962. The Income Tax Act, no. 58 of 1962. Pretoria: Government Printer.

RSA (Republic of South Africa). 1999. The Companies Amendment Act, no. 37 of 1999. Pretoria: Government Printer.

SAICA (South African Institute of Chartered Accountants). 2009a. 'Presentation of financial statements'. IAS 1 (AC 101). Updated: June. Pietermaritzburg: Interpak Books. 
SAICA (South African Institute of Chartered Accountants). 2009b. 'Financial instruments: Presentation'. IAS 32 (AC 125). Updated: January. Pietermaritzburg: Interpak Books.

UK (United Kingdom). 1985. 'The Companies Act, 1985'. [online] URL:http://www.legislation.gov.uk.

Wesson, N. \& Hamman, W.D. 2011. 'Disclosure of share capital: Are reporting standards clear?', Accountancy SA, February, 32-34. 